\title{
The role of beta-adrenergic receptor blockers in autism
}

\author{
Khanh vinh quốc Lương*, Lan Thi Hoàng Nguyễn \\ Vietnamese American Medical Research FoundationWestminster, California, United States \\ Email address: \\ Lng2687765@aol.com(K. v. q. Lương)
}

\section{To cite this article:}

Khanh vinh quốc Lương, Lan Thi Hoàng Nguyễn. The Role of Beta-Adrenergic Receptor Blockers in Autism. American Journal of Psychiatry and Neuroscience. Vol. 1, No. 1, 2013, pp. 14-21. doi: 10.11648/j.ajpn.20130101.13

\begin{abstract}
Genetic studies have identified numerous factors linking $\beta$-adrenergic receptor blockade to autism spectrum disorder (ASD), including $\beta$ adrenergic receptor variants, human leukocyte antigen genes, apoptotics factor caspase-3, glycogen synthetase kinase-3 $\beta$, and the reduced form of nicotinamide adenine dinucleotide phosphate. $\beta$-adrenergic receptor blockade has also been implicated in ASD via its effects on myelin basic protein, prostaglandins, cyclooxygenase- 2 , and nitric oxide synthase. $\beta$ adrenergic receptor blockade may have a significant role in ASD.Therefore, the characterization of $\beta$-adrenergic receptor blockade in individuals with ASD is needed.
\end{abstract}

Keywords: B-Adrenergic Receptor Blocker, Autism, Autism Spectrum Disorder, B-Adrenergic Receptor Antagonism

\section{Introduction}

Autism spectrum disorder (ASD) is a childhood-onset neuro-developmental disorder characterized by disturbances in social interactions, imaginative activities, communication, and speech. A significant association between $\beta$-adrenergic receptors and autism has been demonstrated. In the brain, $\beta$-adrenergic receptors are widely distributed in different regions, including the frontal, parietal, piriform, and retrosplenial cortices; medial septal nuclei; olfactory tubercle; midbrain; striatum; hippocampus; and thalamic nuclei [1-2]. In behavioral tests, newborn rats that were given the $\beta_{2}$-adrenoceptor agonist terbutaline (10 $\mathrm{mg} / \mathrm{kg}$ ) daily on post-natal days 2 to 5 showed consistent patterns of hyper-reactivity to novel and aversive stimuli when assessed in a novel open field, as well as in the acoustic startle response test [3]. These findings indicate that $\beta_{2}$-adrenoceptor over-stimulation during an early critical period results in microglial activation associated with innate neuro-inflammatory pathways and behavioral abnormalities, similar to those described in autism. Term children exposed to tocolysis exhibited a higher rate of psychiatric disorders and poorer cognitive and motor performance than controls [4]. Plasma and urine norepinephrine (NE) levels were increased in ASD patients [5-6]. Individuals with ASD performed more poorly than non-ASD individuals on the working memory test.
Importantly, the administration of propranolol attenuated this impairment, with the ASD group performing significantly better under the propranolol condition than the placebo condition [7]. These findings suggest that NE may play a role in cognitive impairment associated with ASD. Ratley et al. [8] began open trials of $\beta$-adrenergic receptor blockers, as adjunctive medication in eight consecutive autistic adults. The immediate result across all patients was a rapid diminution in aggressive behavior. As time on the drug increased, subtler changes in speech and socialization emerged. Narayanan et al. [9] demonstrated a potential imaging marker for the cognitive effects of propranolol in ASD. Propranolol significantly improved performance in word fluency, but not letter fluency among autism participants [10-11]. More difficult taskswere performed while on propranolol $(40 \mathrm{mg})$ than on placebo; the benefit of $\beta$-adrenergic receptor blockade depends on the difficulty of the cognitive flexibility task and the individual's ability to solve these types of tasks under unstressed conditions [12]. These findings suggest that $\beta$-adrenergic receptor blockade may play a role in autism. In this paper, we discuss the potential role of $\beta$-adrenergic receptor blockers in autism. 


\section{The Genetic Role of $\beta$-adrenergic Receptor Blockers in Autism}

\section{1. $\beta$-Adrenergic Receptor Variants}

Genetic studies provide an excellent opportunity to link molecular variations with epidemiological data. DNA sequence variations, such as polymorphisms, have modest and subtle biological effects. Receptors play a crucial role in the regulation of cellular function, and small changes in their structure can influence intracellular signal transduction pathways. The mechanism by which genetic susceptibility to over-stimulation of the $\beta$-adrenergic receptor is conferred may increase the risk for alterations, such as those that that lead to autism, in neuro-development. Connors et al. [13] found high frequencies of the Gly16 and Glu27 alleles in the $\beta$-adrenergic receptor polymorphisms in individuals with autism. In the Autism Genetic Resource Exchange (AGRE) population, the Glu27 allele of the $\beta_{2^{-}}$ adrenergic receptor gene also conferred an increased risk of autism [14].

\subsection{The Human Leukocyte Antigen (HLA)}

Studies have suggested that HLA genes are located in the major histocompatibility complex (MHC) class II molecule region. HLA genes have been implicated in autism susceptibility. A number of cellular activation markers, including HLA-DR and CD26 on $\mathrm{T}$ cells, were significantly increased in an autism group compared with controls [15]. HLA-DRBI has been associated with autism in Caucasians and Han Chinese [16-20]. Higher frequencies of the DR4 allele have been shown to exist in autistic Caucasians [21-22], but the frequencies were lower in autistic Han Chinese compared with controls [20]. The HLA-DR4 gene may be expressed in the mothers of children with autism during pregnancy, contributing to autism in their offspring [21]. The DR13 allele is also associated with autism in Caucasians [17] but not in Han Chinese [20]. Patients with autism and the DR4, DR11, or $D R 14$ alleles performed differently on intelligence and neuro-psychology tests compared with controls [20]. The haplotype B44-SC30-DR4 was also associated with autism in Caucasians [22-23]. Moreover, a correlation between $H L A-D R$ and $H L A-D Q$ gene polymorphisms and the anti- $\beta$ receptor antibodies in familial cardiomyopathy has been suggested [24]. Cardiac $\beta$-adrenergic receptors and adenylatecyclase activity in dilated cardiomyopathy have been shown to be modulated by circulating autoantibodies against the cardiac $\beta_{1}$-adrenoceptor, the presence of which isregulated bythe HLA-DR gene [25]. Propranolol abrogated interferon-gamma (IFN- $\gamma$ )-induced increases in HLA class II expression and interleukin-1beta (IL-1 $\beta$ ) secretion [26]. HLA-DR expression was significantly reduced in the lymphocytes of carvedilol-treated congestive heart failure (CHF) patients [27]. These findings suggest that $\beta$-adrenergic receptor blockers may affect ASD via the suppression of MHC class II antigen expression.

\subsection{Apoptotic Factor Caspases}

Caspases are cysteinyl aspartate-specific proteases that play a critical role in the regulatory and execution phases of apoptosis [28]. Neonatal exposure to sevoflurane, an anesthetic, significantly increased the number of apoptotic cells and increased cleaved caspase-3 in the brain. Sevoflurane also induced abnormal social behaviors and deficits in mouse fear conditioning [29]. Caspase-3 increased in the cerebella of participants with autism [30]. The expression of caspases also increased in the peripheral blood mononuclear cells of patients with ASD [31]. Moreover, $\beta_{1}$-selective adrenoceptor antagonism effectively inhibited NE-induced apoptosis in adult rat ventricular myocytes [32]. D-propranolol suppressed caspase-3 activation by $63 \%$ and preserved cell survival to $88 \%$ of the control value in cases of lysosomal iron accumulation and oxidative injury in endothelial cells [33]. $\beta$-adrenoceptor blockers protect against staurosporine-induced apoptosis in SH-SY5Y neuroblastoma cells. Propranolol and ICI 118551, but not atenolol, demonstrated a concentrationdependent inhibition of caspase-3-like activity [34]. These findings suggest that $\beta$-adrenergic receptor antagonists may influence the onset of autism through the suppression of apoptotic factor caspase-3.

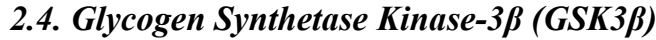

GSK3 $\beta$ is a protein kinase that is involved in many physiological processes (e.g., metabolism, gene expression and apoptosis). GSK3 $\beta$ is pivotal in controlling neuronal polarity within primary embryonic hippocampal neurons [35]. Mice with a fragile X retardation 1 (Fmrl) gene deletion are used to model autistic behaviors. The inhibitory serine phosphorylation of GSK3 $\beta$ is lower in the brain regions of Fmrl knockout mice than in those of wildtype mice [36]. The impaired inhibition regulation of GSK3 $\beta$ in Fmr1 knockout mice may contribute to some socialization deficits, and lithium treatment can ameliorate certain socialization impairments [36-38]. The expression of mutant Tph2 in mice results in a marked reduction $(\sim 80 \%)$ in brain serotonin (5-HT) production and leads to behavior abnormalities in emotional states. GSK3 $\beta$ activation accompanies this reduction in brain 5-HT levels. The inactivation of GSK3 $\beta$ in Tph2 knock-out mice, either using pharmacological or genetic approaches, alleviates the aberrant behaviors produced by a 5-HT deficiency [39]. Furthermore, the Wnt/ $\beta$-catenin pathway plays a critical role in the proliferation, differentiation, apoptosis, and cell outgrowth processes of the CNS during embryonic development [40]. The dysregulation of the Wnt pathway may contribute to the pathogenesis of neurodevelopmental disorders such as autism. Sundilac, an inhibitor of the Wnt/ $\beta$-catenin pathway, decreased activated GSK3 $\beta$ levels and ameliorated repetitive/stereotypic activity, as well as the learning, memory, and behavioral abnormalities found in rat autism models [41]. Moreover, constitutive GSK3 $\beta$ activity protects against chronic $\beta$-adrenergic remodeling of 
the heart [42]. Propranolol restores cognitive deficits and improves amyloid and Tau pathologies in a senescenceaccelerated mouse model, which was associated with an increase in GSK3 $\beta$ phosphorylation [43-44]. Taken together, these findings suggest that $\beta$-adrenergic receptor blockers may play a role in autism by modulating GSK3 $\beta$ activity.

\subsection{The Reduced Form of the Nicotinamide Adenine Dinucleotide Phosphate (NADPH) Oxidase (NOX) Enzyme Complex}

NOX mediates critical physiological and pathological processes including cell signaling, inflammation and mitogenesis, by generating reactive oxygen species (ROS) from molecular oxygen. Mitochondrial dysfunction and altered energy metabolism may influence the social and cognitive deficits present in patients with autism. The NOX activity in the lymphocytic mitochondria of children with autism was significantly lower than that in controls [45]. Levels of plasma ATP and red blood cell NADH were reported to be lower in children with autism than in controls. Vitamin and mineral supplements were associated with a greater significant improvement in ATP and NADH levels, as well as hyperactivity, tantrum, and receptive language subscores, in the autism group compared with the placebo group [46-47]. In addition, gene variants of the NADH-ubiquinone oxido-reductase 1asubcomplex 5 (NDUFA5), an enzyme complex in the mitochondrial electron transport chain, are associated with autism [48]. Moreover, nebivolol, a third-generation selective $\beta_{1^{-}}$ adrenoceptor, improved left ventricle dysfunction and survival immediately after myocardial ischemia and inhibited cardiac NOX activation [49]. Nebivolol treatment has been associated with improvements in insulin resistance, reduced proteinuria and NOX activity, and the production of reactive oxygen speciesin the kidneys and skeletal muscle tissue of transgenic TG (mRen2)27 rats (Ren2) [50-51]. Nebivolol also improved diastolic relaxation, fibrosis, and remodeling in obese Zucker rats, and reduced NOX-dependent superoxide production [52]. Carvedilol attenuated the increased expression of NOX subunits in the hearts and kidneys of rats after daunorubicin-induced cardiotoxicity and nephrotoxicity [53]. NOX activity in whole blood and isolated neutrophils was dose-dependently inhibited by nebivolol, whereas atenolol, metoprolol, and carvedilol were markedly less effective in Watanabe heritable hyperlipidemic rabbits [54]. Celiprolol, a specific $\beta_{1}$-receptor antagonist with weak $\beta_{2}$ receptor agonistic activity, suppressed NOX p $22^{\text {phox }}, \mathrm{p} 47^{\text {phox }}$, gp91phox, and Nox1 expression in the left ventricle of deoxycorticosterone acetate (DOCA)-salt hypertensive rats [55].Taken together, these findings suggest that $\beta$ adrenergic receptor antagonists play a role in autism through the suppression of NADPH expression.

\section{The Non-genomic Role of $\beta$-adrenergic Receptor Blockers in Autism}

\subsection{Myelin Basic Protein (MBP)}

Immune comorbidities often are reported in subsets of patients with neuro-developmental disorders, including ASD and attention-deficit hyperactivity disorder. A common immunopathology is an increase in serum autoantibodies against neuron-axon filament protein (antiNAFP), glial fibrillary acidic protein (anti-GFAP) and MBP relative to control patients. Increases in autoantibodies suggest possible deficits in self-tolerance that may contribute to the formation of brain-specific autoantibodies and subsequent effects on the central nervous system (CNS) [56-57]. In midline structures including the region of the absent corpus callosum of BTBR mouse model of autisticlike behavior revealed selective changes in neurodevelopmental proteins and adult hippocampal neurogenesis; the myelin markers 2', 3'-cyclic nucleotide 3'-phosphodiesterase (CNPase) and MBP were reduced [58]. A magnetization transfer imaging study of corpus callosum myelination was significantly higher in children with autism than in typically developing children, suggesting abnormal myelination of the corpus callosum in autism [59]. Autistic children had significantly higher serum levels of serotonin and anti-MBP auto-antibodies than healthy children. However, serum serotonin levels had no significant correlations with serum levels of anti-MBP auto-antibodies in autistic patients [60]. Markham et al. [61] demonstrated that the sensitivity of myelination to experience is reduced in adulthood relative to development in both sexes. High serum anti-NBP antibodies were reported in Egyptian autistic children [62]. Antibodies MBP against fetal brain were revealed in sera of mothers with autistic children [63]. Transmission disequilibrium study suggested that an oligodendrocyte and myelin glycoprotein gene allele was associated with families with an autistic proband [64]. However, high-affinity muscarinic cholinergic receptors were detected in myelin purified from rat brain stem with use of the radioligands $3 \mathrm{H}-\mathrm{N}-$ methylscopolamine (3H-NMS), 3H-quinuclidinyl benzilate (3H-QNB), and 3H-pirenzepine. 3H-NMS binding was also present in myelin isolated from corpus callosum [65]. The possibility that some of these muscarinic receptors may be involved in regulation of phosphinositide metabolism and the protein kinase activities of myelin is considered. A novel clonal cell line derived from a human glioma (HOG) was found to express some oligodendrocyte-specific proteins including a $15-\mathrm{kDa}$ form of myelin basic protein (MBP) and high 2',3'-cyclic nucleotide 3'phosphodiesterase (CNPase) activity. Receptor types expressed by $\mathrm{HOG}$ cells included $\mathrm{A}_{2}$-adenosine, prostaglandin $\mathrm{E} 1$, and $\beta_{2}$-adrenergic receptors linked to stimulation of adenylatecyclase [66]. Vroon et al. [67] demonstrated that induction of experimental autoimmune 
encephalomyelitis (EAE) by myelin oligodendrocyte glycoprotein (MOG) resulted in a profound decrease in Gprotein-coupled receptor kinases (GRK), including GRK2 and GRK6 protein, in splenocytes during all phases of disease. GRK2 mRNA was also lower during EAE. Canine distemper (CD) virus primarily infects astrocytes and causes a demyelinating disease in dogs that closely resembles multiple sclerosis (MS). In control dogs, including three dogs with another inflammatory disease, $\beta_{2}$ adrenergic receptor immuno-reactivity was observed on both neurons and astrocytes. In dogs with CD encephalitis, $\beta_{2}$-adrenergic receptors were present on neurons, but were absent on astrocytes in acute lesions, demyelinated lesions, and normal-appearing white matter [68]. In MS, De Keyser et al. [69] found that astrocytes, not only in plaques but also in normal-appearing white matter, lack $\beta_{2}$-adrenergic receptors. This abnormality might play a crucial role in the pathophysiology of MS. Taken together, $\beta_{2}$-adrenergic receptor blockers may have a role in autism by modulating myelin formation.

\subsection{Prostaglandins (PGs) and Cyclooxygenase (COX)}

PGs play a role in inflammatory processes. COX participates in the conversion of arachidonic acid into PGs. These released prostanoids play an important role in normal neural function, including spatial learning, synaptic plasticity and long-term potentiation [70]. The $\mathrm{PGE}_{2}$ signaling pathway may have an important role in early development; the expression of four EP (E-prostanoid) receptor' transcripts $\left(\mathrm{EP}_{1}, \mathrm{EP}_{2}, \mathrm{EP}_{3} \beta\right.$, and $\left.\mathrm{EP}_{4}\right)$ significantly increases in mouse embryos from Days 11-15 [71]. The normal laminar pattern of COX-2 expression- in the human cortex is altered in patients with Rett syndrome, a type of ASD [72]. There is an association between the PTGS2 polymorphism (the gene that encodes the COX-2 enzyme) and Korean trios with ASD [73]. Moreover, epinephrine increases the release of $\mathrm{PGE}_{2}$ in human colon adenocarcinoma HT-29 cells, which can be blocked by COX-2 inhibitors or atenolol and ICI 118,551 ( $\beta_{1^{-}}$and $\beta_{2^{-}}$ selective receptor adrenergic antagonists, respectively) [74] $\beta_{2}$-adrenergic receptor antagonists suppress COX-2 expression in pancreatic cancer cells [75]. Propranolol inhibited cell proliferation and repressedgastric cancer cell growth through the downstream COX-2 pathway [76-77]. In addition, the administration of propranolol and a COX-2 inhibitor, which can be applied peri-operatively in most cancer patients with minimal risk and low cost, counteracted several immunological and endocrinological perturbations and improved recurrence-free survival rates in mice undergoing primary tumor excision [78-79].These findings suggest that $\beta$-adrenergic receptor antagonists may play a role in modulating the inflammatory process in ASD.

\subsection{Reactive Oxygen Species (ROS)}

ROS play a major role in various cell-signaling pathways ROS activate various transcription factors and increase the expression of proteins that control cellular transformation, tumor cell survival, tumor cell proliferation and invasion, angiogenesis, and metastasis. Lipid peroxidation is a chain reaction between polyunsaturated fatty acids and ROS, and it produces both lipid peroxides and hydrocarbon polymers, which are highly toxic to the cell. Malonyldialdehyde (MDA) is an end product of the peroxidation of polyunsaturated fatty acids. Lipid peroxidation is elevated in individuals with autism. The plasma MDA level is significantly higher in individuals with autism than in their siblings without autism [80]. Higher serum MDA and 8hydroxy-2-deoxyguanosine (8OHdG) levels were found in children with autism compared with controls [81]. 8OHdD levels were also increased in the cerebellum of patients with autism [82-83]. The $\mathrm{F}_{2}$-isoprostane 8-isoprostaglandin $F_{2} \alpha$ is enhanced in children with autism [84].This isoprostane is a product of nonenzymatic oxidation of arachidonic acid and suggested as a marker of lipid peroxidation. Compared with controls, children with autism had significantly higher urinary levels of isoprostane $\mathrm{F}_{2} \alpha$-VI (2,3-dinor-thromboxane $\mathrm{B}_{2}$, a marker of lipid peroxidation) and 6-keto-prostaglandin $\mathrm{F}_{1} \alpha$ [85]. The erythrocyte superoxide dismutase (SOD) activity in children with autism was significantly lower than that in normal controls [86]. The glutathione (GSH) plays an important role in a several cellular process including cell differentiation, proliferation, and apoptosis. GSH content was significantly lower in patients with autism compared with the control group [82, 87]. Moreover, myocardial tissue sections display increased ROSlevels after traumatic brain injuries. Treatment with propranolol reduced cardiac ROS levels [88]. D-propranolol attenuated lysosomal iron accumulation and oxidative injury in endothelial cells [33]. Carvedilol modulated ROS-induced signaling, and it significantly reduced ischemia-reperfusion-induced free radical production and $\mathrm{NAD}^{+}$catabolism, lipid peroxidation and red blood cell membrane damage, as determined by the assessment of free MDA production in heart perfusion and rheological models [89]. Carvedilol also protected against colcichine- and aluminum-induced neuro-toxicity in rats by attenuating oxidative stress, including lipid peroxidation, and nitrite concentration; restoring reduced GSH, SOD, catalase, and GSH Stransferase activity; and improving the memory performance of rats in the Morris water maze test [90-91]. Nebivolol improved diastolic dysfunction and myocardial remodeling by reducing oxidative stress in the transgenic (mRen2) rat [92]. These findings suggest that $\beta$-adrenergic receptor antagonists modulate oxidative stress in autism.

\subsection{Nitric Oxide Synthase (NOS)}

NOS is an enzyme involved in the synthesis of nitric oxide (NO), which regulates a variety of important physiological responses including cell migration, immune responses, and apoptosis. NO affects the development and function of the CNS. Specifically, NO enhances the release of dopamine in the striatum in animal models [93]. 
Extracellular dopamine increased following the intrastriatal infusion of NOS substrate [94]. Increased RBC NO levels and plasma GSH peroxidase (GSH-Px) were detected in patients with autism [95]. In addition, GSH plasma levels were decreased in children with autism compared with agematched controls [96-97]. GSH pathway gene variations are associated with ASD [98-100]. Moreover, metipranolol suppressed NO-induced lipid peroxidation in the eyes and retinas of rats [101]. Nebivolol prevented vascular NOS III uncoupling in experimental hyperlipidemia [54]. Propranolol suppressed hemangioma growth through the inhibition of eNOS protein expression and the subsequent production of nitric oxide [102]. Celiprolol activated eNOS through the PI3K-Akt pathway via oxidative stress-induced NF-KBactivity [55]. These findings suggest that $\beta$ adrenergic receptor antagonists may play a role in ASDvia the inhibition of NOS expression.

\section{Conclusion}

$\beta$-adrenergic receptor blockade may play a role in ASD. Genetic studies have aided the identification of proteins that link $\beta$-adrenergic receptor antagonism to the pathology ofASD, including $\beta$-adrenergic receptor variants, human leukocyte antigen genes, apoptotics factor caspase-3, glycogen synthetase kinase- $3 \beta$, and the reduced form of nicotinamide adenine dinucleotide phosphate. $\beta$-adrenergic receptor inhibition also affects ASD via non-genomic mechanisms, including myelin basic protein, prostaglandins, cyclooxygenase-2, and nitric oxide synthase. Thus, further examination of the relationship between $\beta$-adrenergic receptor antagonistsandASD is required.

\section{Acknowledgment}

Conflict of interest statement: The authors declare that there are no competing interests.

Ethics approval: Not applicable

Funding: The authors declare that they have received no funding.

\section{References}

[1] Asanuma M, Ogawa N, Mizukawa K, Haba K, Hirata H, Mori A. Distribution of the beta-2 adrenergic receptor messenger RNA in the rat brain by in situ hybridization histochemistry: effects of chronic reserpine treatment. Neurochem Res. 1991;16:1253-6.

[2] Nicholas AP, Pieribone VA, Hökfelt T. Cellular localization of messenger RNA for beta-1 and beta-2 adrenergic receptors in rat brain: an in situ hybridization study. Neuroscience. 1993;56:1023-39.

[3] Zerrate MC, Pletnikov M, Connors SL, Vargas DL, Seidler FJ, et al. Neuroinflammation and behavioral abnormalities after neonatal terbutaline treatment in rats: implications for autism. J PharmacolExpTher. 2007;322:16-22.
[4] Pitzer M, Schmidt MH, Esser G, Laucht M. Child development after maternal tocolysis with betasympathomimetic drugs. Child Psychiatry Hum Dev. 2001;31:165-82.

[5] Lake CR, Ziegler MG, Murphy DL. Increased norepinephrine levels and decreased dopamine-betahydroxylase activity in primary autism. Arch Gen Psychiatry. 1977;34:553-6.

[6] Barthelemy C, Bruneau N, Cottet-Eymard JM, DomenechJouve J, Garreau B, et al. Urinary free and conjugated catecholamines and metabolites in autistic children. $\mathrm{J}$ Autism DevDisord. 1988;18:583-91.

[7] Bodner KE, Beversdorf DQ, Saklayen SS, Christ SE. Noradrenergic moderation of working memory impairments in adults with autism spectrum disorder. J IntNeuropsychol Soc. 2012;18:556-64.

[8] Ratey JJ, Bemporad J, Sorgi P, Bick P, Polakoff S, et al. Open trial effects of beta-blockers on speech and social behaviors in 8 autistic adults. $\mathrm{J}$ Autism DevDisord. 1987; 17:439-46.

[9] Narayanan A, White CA, Saklayen S, Scaduto MJ, Carpenter AL, et al. Effect of propranolol on functional connectivity in autism spectrum disorder--a pilot study. Brain Imaging Behav. 2010;4:189-97.

[10] Beversdorf DQ, Saklayen S, Higgins KF, Bodner KE, Kanne SM, Christ SE. Effect of propranolol on word fluency in autism. CognBehav Neurol. 2011;24:11-7

[11] Beversdorf DQ, Carpenter AL, Miller RF, Cios JS, Hillier A. Effect of propranolol on verbal problem solving in autism spectrum disorder. Neurocase. 2008;14:378-83.

[12] Campbell HL, Tivarus ME, Hillier A, Beversdorf DQ. Increased task difficulty results in greater impact of noradrenergic modulation of cognitive flexibility. PharmacolBiochemBehav. 2008;88:222-9.

[13] Connors SL, Crowell DE, Eberhart CG, Copeland J, Newschaffer CJ, et al. $\beta_{2}$-adrenergicreceptor activation and genetic polymorphisms in autism: data from dizygotic twins. J Child Neurol. 2005;20:876-84.

[14] Cheslack-Postava K, Fallin MD, Avramopoulos D, Connors $\mathrm{SL}$, Zimmerman AW, et al. $\beta_{2}$-Adrenergicreceptor gene variants and risk for autism in the AGRE cohort. Mol Psychiatry. 2007;12:283-91.

[15] Ashwood P, Corbett BA, Kantor A, Schulman H, Van de Water J, Amaral DG. In search of cellular immunophenotypes in the blood of children with autism. PLoS One. 2011;6:e19299.

[16] Warren RP, Odell JD, Warren WL, Burger RA, Maciulis A, et al. Strong association of the third hypervariable region of HLA-DR beta 1 with autism. J Neuroimmunol. 1996;67:97102.

[17] Torres AR, Maciulis A, Stubbs EG, Cutler A, Odell D. The transmission disequilibrium test suggests that HLA-DR4 and DR13 are linked to autism spectrum disorder. Hum Immunol. 2002;63:311-6.

[18] Grady DL, Harxhi A, Smith M, Flodman P, Spence MA, et al. Sequence variants of the DRD4 gene in autism: further evidence that rare DRD4 7R haplotypes are ADHD specific. 
Am J Med Genet B Neuropsychiatr Genet. 2005;136B:33-5.

[19] Lee LC, Zachary AA, Leffell MS, Newschaffer CJ, Matteson KJ, et al. HLA-DR4 in families with autism. Pediatr Neurol. 2006;35:303-7.

[20] Chien YL, Wu YY, Chen CH, Gau SS, Huang YS, et al. Association of HLA-DRB1 alleles and neuropsychological function in autism. Psychiatr Genet. 2012;22:46-9.

[21] Johnson WG, Buyske S, Mars AE, Sreenath M, Stenroos ES, et al. HLA-DR4 as a risk allele for autism acting in mothers of probands possibly during pregnancy.Arch PediatrAdolesc Med. 2009;163:542-6.

[22] Odell D, Maciulis A, Cutler A, Warren L, McMahon WM, et al. Confirmation of the association of the C4B null allelle in autism. Hum Immunol. 2005;66:140-5

[23] Daniels WW, Warren RP, Odell JD, Maciulis A, Burger RA, et al. Increased frequency of the extended or ancestral haplotype B44-SC30-DR4 in autism. Neuropsychobiology. 1995;32:120-3.

[24] Limas C, Limas CJ, Boudoulas H, Bair R, Graber H, et al. Anti-beta-receptor antibodies in familial cardiomyopathy: correlation with HLA-DR and HLA-DQ gene polymorphisms. Am Heart J. 1994;127:382-6.

[25] Limas CJ, Goldenberg IF, LimasC.Influence of anti-betareceptor antibodies on cardiac adenylatecyclase in patients with idiopathic dilated cardiomyopathy. Am Heart J. 1990;119:1322-8.

[26] Li Q, Milo R, Panitch H, Bever CT Jr. Effect of propranolol and IFN-beta on the induction of MHC class II expression and cytokine production by IFN-gamma IN THP-1 human monocytic cells. Immunopharmacol Immunotoxicol. 1998;20:39-61.

[27] Shaw SM, Coppinger T, Waywell C, Dunne L, Archer LD, et al. The effect of beta-blockers on the adaptive immune system in chronic heart failure. Cardiovasc Ther. 2009;27:181-6.

[28] Salvesen GS, Riedl SJ. Caspase mechanisms. Adv Exp Med Biol. 2008;615:13-23.

[29] Satomoto M, Satoh Y, Terui K, Miyao H, Takishima K, et al. Neonatal exposure to sevoflurane induces abnormal social behaviors and deficits in fear conditioning in mice. Anesthesiology 2009;110:628-37.

[30] Sheikh AM, Li X, Wen G, Tauqeer Z, Brown WT, Malik M. Cathepsin D and apoptosis related proteins are elevated in the brain of autistic subjects. Neuroscience. 2010;165:36370.

[31] Siniscalco D, Sapone A, Giordano C, Cirillo A, de Novellis $\mathrm{V}$, et al. The Expression of Caspases is Enhanced in Peripheral Blood Mononuclear Cells of Autism Spectrum Disorder Patients. J Autism Dev Disord. 2012;42:1403-10.

[32] Zaugg M, Xu W, Lucchinetti E, Shafiq SA, Jamali NZ, Siddiqui MA. Beta-adrenergic receptor subtypes differentially affect apoptosis in adult rat ventricular myocytes. Circulation. 2000 18;102:344-50.

[33] Mak IT, Chmielinska JJ, Nedelec L, Torres A, Weglicki WB. D-propranolol attenuates lysosomal iron accumulation and oxidative injury in endothelial cells. J Pharmacol Exp Ther.
$2006 ; 317: 522-8$

[34] Mikami M, Goubaeva F, Song JH, Lee HT, Yang J.betaAdrenoceptor blockers protect against staurosporineinduced apoptosis in SH-SY5Y neuroblastoma cells. Eur J Pharmacol. 2008;589:14-21.

[35] Jiang H, Guo W, Liang X, Rao Y. Both the establishment and the maintenance of neuronal polarity require active mechanisms: critical roles of GSK-3beta and its upstream regulators. Cell. 2005;120:123-35.

[36] Yuskaitis CJ, Beurel E, Jope RS. 1. Evidence of reactive astrocytes but not peripheral immune system activation in a mouse model of Fragile X syndrome. Biochim Biophys Acta 2010;1802:1006-1012.

[37] Min WW, Yuskaitis CJ, Yan Q, Sikorski C, Chen S, et al. Elevated glycogen synthase kinase-3 activity in Fragile $\mathrm{X}$ mice: key metabolic regulator with evidence for treatment potential. Neuropharmacology. 2009;56:463-72.

[38] Mines MA, Yuskaitis CJ, King MK, Beurel E, Jope RS. GSK3 influences social preference and anxiety-related behaviors during social interaction in a mouse model of fragile X syndrome and autism. PLoS One. 2010;5:e9706.

[39] Beaulieu JM, Zhang X, Rodriguiz RM, Sotnikova TD, Cools MJ, et al. Role of GSK3 beta in behavioral abnormalities induced by serotonin deficiency. Proc Natl Acad Sci U S A. 2008;105:1333-8.

[40] Ciani L, Salinas PC. WNTs in the vertebrate nervous system: from patterning to neuronal connectivity. Nat Rev Neurosci. $2005 ; 6: 351-62$.

[41] Zhang Y, Sun Y, Wang F, Wang Z, Peng Y, Li R. Downregulating the Canonical Wnt/ $\beta$-catenin Signaling Pathway Attenuates the Susceptibility to Autism-like Phenotypes by Decreasing Oxidative Stress. Neurochem Res. 2012;37:1409-19

[42] Webb IG, Nishino Y, Clark JE, Murdoch C, Walker SJ, et al. Constitutive glycogen synthase kinase-3alpha/beta activity protects against chronic beta-adrenergicremodelling of the heart. Cardiovasc Res. 2010;87:494-503.

[43] Dobarro M, Orejana L, Aguirre N, RamírezMJ.Propranolol reduces cognitive deficits, amyloid $\beta$ levels, tau phosphorylation and insulin resistance in response to chronic corticosterone administration. Int J Neuropsychopharmacol. 2012 Nov 30:1-10.

[44] Dobarro M, Orejana L, Aguirre N, Ramírez MJ. Propranolol restores cognitive deficits and improves amyloid and Tau pathologies in a senescence-accelerated mouse model. Neuropharmacology. 2013;64:137-44.

[45] Giulivi C, Zhang YF, Omanska-Klusek A, Ross-Inta C, Wong S, et al. Mitochondrial dysfunction in autism. JAMA. 2010;304:2389-96.

[46] Adams JB, Audhya T, McDonough-Means S, Rubin RA, Quig D, et al. Nutritional and metabolic status of children with autism vs. neurotypical children, and the association with autism severity. Nutr Metab (Lond). 2011;8:34.

[47] Adams JB, Audhya T, McDonough-Means S, Rubin RA, Quig D, et al. Effect of a vitamin/mineral supplement on children and adults with autism. BMC Pediatr. 2011;11:111. 
[48] Marui T, Funatogawa I, Koishi S, Yamamoto K, Matsumoto $\mathrm{H}$, et al. The NADH-ubiquinone oxidoreductase 1 alpha subcomplex 5 (NDUFA5) gene variants are associated with autism. Acta Psychiatr Scand. 2011;123:118-24.

[49] Sorrentino SA, Doerries C, Manes C, Speer T, Dessy C, et al. Nebivolol exerts beneficial effects on endothelial function, early endothelial progenitor cells, myocardial neovascularization, and left ventricular dysfunction early after myocardial infarction beyond conventional $\beta 1$ blockade. J Am Coll Cardiol. 2011;57:601-11.

[50] Manrique C, Lastra G, Habibi J, Pulakat L, Schneider R, et al. Nebivolol improves insulin sensitivity in the TGR(Ren2)27 rat. Metabolism. 2011;60:1757-66.

[51] Whaley-Connell A, Habibi J, Johnson M, Tilmon R, Rehmer $\mathrm{N}$, et al. Nebivolol reduces proteinuria and renal NADPH oxidase-generated reactive oxygen species in the transgenic Ren2 rat. Am J Nephrol. 2009;30:354-60.

[52] Zhou X, Ma L, Habibi J, Whaley-Connell A, Hayden MR, et al. Nebivolol improves diastolic dysfunction and myocardial remodeling through reductions in oxidative stress in the Zucker obese rat. Hypertension. 2010;55:880-8.

[53] Arozal W, Watanabe K, Veeraveedu PT, Ma M, Thandavarayan RA, et al. Protective effect of carvedilol on daunorubicin-induced cardiotoxicity and nephrotoxicity in rats. Toxicology. 2010;274:18-26.

[54] Mollnau H, Schulz E, Daiber A, Baldus S, Oelze M, et al. Nebivolol prevents vascular NOS III uncoupling in experimental hyperlipidemia and inhibits NADPH oxidase activity in inflammatory cells. Arterioscler Thromb Vasc Biol. 2003;23:615-21.

[55] Kobayashi N, Mita S, Yoshida K, Honda T, Kobayashi T, et al.Celiprolol activates eNOS through the PI3K-Akt pathway and inhibits VCAM-1 Via NF-kappaB induced by oxidative stress. Hypertension. 2003;42:1004-13.

[56] Singh VK, Warren R, Averett R, Ghaziuddin M. Circulating autoantibodies to neuronal and glial filament proteins in autism. Pediatr Neurol. 1997;17:88-90.

[57] Singh VK, Warren RP, Odell JD, Warren WL, Cole P. Antibodies to myelin basic protein in children with autistic behavior. Brain Behav Immun. 1993;7:97-103.

[58] Stephenson DT, O'Neill SM, Narayan S, Tiwari A, Arnold E, et al.Histopathologic characterization of the BTBR mouse model of autistic-like behavior reveals selective changes in neurodevelopmental proteins and adult hippocampal neurogenesis. Mol Autism.2011;2:7.

[59] Gozzi M, Nielson DM, Lenroot RK, Ostuni JL, Luckenbaugh DA, et al. A magnetization transfer imaging study of corpus callosum myelination in young children with autism. Biol Psychiatry. 2012;72:215-20.

[60] Mostafa GA, Al-Ayadhi LY. A lack of association between hyperserotonemia and the increased frequency of serum anti-myelin basic protein auto-antibodies in autistic children. J Neuroinflammation. 2011;8:71.

[61] Markham JA, Herting MM, Luszpak AE, Juraska JM, Greenough WT. Myelination of the corpus callosum in male and female rats following complex environment housing during adulthood. Brain Res. 2009;1288:9-17.
[62] Mostafa GA, El-Sayed ZA, El-Aziz MM, El-Sayed MF. Serum anti-myelin-associated glycoprotein antibodies in Egyptian autistic children. J Child Neurol. 2008;23:1413-8.

[63] Singer HS, Morris CM, Gause CD, Gillin PK, Crawford S, Zimmerman AW. Antibodies against fetal brain in sera of mothers with autistic children. J Neuroimmunol. 2008;194:165-72.

[64] Martin I, Gauthier J, D'Amelio M, Védrine S, Vourc'h P, et al. Transmission disequilibrium study of an oligodendrocyte and myelin glycoprotein gene allele in 431 families with an autisticproband. Neurosci Res. 2007;59:426-30.

[65] Larocca JN, Ledeen RW, Dvorkin B, Makman MH. Muscarinic receptor binding and muscarinic receptormediated inhibition of adenylatecyclase in rat brain myelin. J Neurosci. 1987;7:3869-76.

[66] Post GR, Dawson G. Characterization of a cell line derived from a human oligodendroglioma. Mol Chem Neuropathol. 1992;16:303-17.

[67] Vroon A, Lombardi MS, Kavelaars A, Heijnen CJ. Changes in the G-protein-coupled receptor desensitization machinery during relapsing-progressive experimental allergic encephalomyelitis. J Neuroimmunol. 2003;137:79-86.

[68] De Keyser J, Wilczak N, Walter JH, Zurbriggen A. Disappearance of $\beta_{2}$-adrenergicreceptors on astrocytes in canine distemper encephalitis: possible implications for the pathogenesis of multiple sclerosis. Neuroreport. 2001;12:191-4.

[69] De Keyser J, Wilczak N, Leta R, Streetland C. Astrocytes in multiple sclerosis lack beta-2 adrenergic receptors. Neurology. 1999;53:1628-33.

[70] Tassoni D, Kaur G, Weisinger RS, Sinclair AJ. The role of eicosanoids in the brain. Asia Pac J Clin Nutr. 2008;17Suppl $1: 220-8$.

[71] Tamiji J, Crawford DA. Prostaglandin $E_{2}$ and misoprostol induce neurite retraction in Neuro-2a cells. Biochem Biophys Res Commun. 2010;98:450-6.

[72] Kaufmann WE, Worley PF, Taylor CV, Bremer M, Isakson PC. Cyclooxygenase-2 expression during rat neocortical development and in Rett syndrome. Brain Dev. 1997;19:2534 .

[73] Yoo HJ, Cho IH, Park M, Cho E, Cho SC, et al. Association between PTGS2 polymorphism and autism spectrum disorders in Korean trios. Neurosci Res. 2008;62:66-9.

[74] Wong HP, Ho JW, Koo MW, Yu L, Wu WK, et al. Effects of adrenaline in human colon adenocarcinoma HT-29 cells. Life Sci. 2011;88:1108-12.

[75] Zhang D, Ma QY, Hu HT, Zhang M. $\beta_{2}$-adrenergic antagonists suppress pancreatic cancer cell invasion by inhibiting CREB, NFKB and AP-1. Cancer Biol Ther.2010;10:19-29.

[76] Liao X, Che X, Zhao W, Zhang D, Bi T, Wang G. The $\beta$ adrenoceptor antagonist, propranolol, induces human gastric cancer cell apoptosis and cell cycle arrest via inhibiting nuclear factor $\kappa B$ signaling. Oncol Rep. 2010;24:1669-76.

[77] Liao X, Che X, Zhao W, Zhang D, Long H, et al. Effects of propranolol in combination with radiation on apoptosis and 
survival of gastric cancer cells in vitro. Radiat Oncol. 2010;5:98.

[78] Glasner A, Avraham R, Rosenne E, Benish M, Zmora O, et al. Improving survival rates in two models of spontaneous postoperative metastasis in mice by combined administration of a beta-adrenergic antagonist and a cyclooxygenase-2 inhibitor. J Immunol. 2010;184:2449-57.

[79] Benish M, Bartal I, Goldfarb Y, Levi B, Avraham R, et al.Perioperative use of beta-blockers and COX-2 inhibitors may improve immune competence and reduce the risk of tumor metastasis. Ann Surg Oncol. 2008;15:2042-52.

[80] Chauhan A, Chauhan V, Brown WT, Cohen I. Oxidative stress in autism: increased lipid peroxidation and reduced serum levels of ceruloplasmin and transferrin--the antioxidant proteins. Life Sci. 2004;75:2539-49.

[81] González-Fraguela M, Hung M, Vera H, Maragoto C, Noris $\mathrm{E}$, et al. Oxidative stress markers in children with autism spectrum disorders. British J Med Medical Res. 2013;3:30717.

[82] Sajdel-Sulkowska E, Lipinski B, Windom H, Audhya J, McGinnis W. Oxidative stress in autism: cerebellar 3 nitrotyrosine levels. Am J Biochem Biotechnol. 2008;4:7384.

[83] Rose S, Melnyk S, Pavliv O, Bai S, Nick TG, et al. Evidence of oxidative damage and inflammation associated with low glutathione redox status in the autism brain. Transl Psychiatry. 2012;2:e134

[84] Ming X, Stein TP, Brimacombe M, Johnson WG, Lambert $\mathrm{GH}$, Wagner GC. Increased excretion of a lipid peroxidation biomarker in autism. Prostaglandins Leukot Essent Fatty Acids. 2005;73:379-84.

[85] Yao Y, Walsh WJ, McGinnis WR, Praticò D. Altered vascular phenotype in autism: correlation with oxidative stress. Arch Neurol. 2006;63:1161-4.

[86] Yorbik O, Sayal A, Akay C, Akbiyik DI, Sohmen T. Investigation of antioxidant enzymes in children with autistic disorder. Prostaglandins LeukotEssent Fatty Acids. $2002 ; 67: 341-3$

[87] Al-Gadani Y, El-Ansary A, Attas O, Al-Ayadhi L. Metabolic biomarkers related to oxidative stress and antioxidant status in Saudi autistic children. Clin Biochem.2009;42:1032-40.

[88] Larson BE, Stockwell DW, Boas S, Andrews T, Wellman $\mathrm{GC}$, et al. Cardiac reactive oxygen species after traumatic brain injury. J Surg Res. 2012;173:e73-81.

[89] Habon T, Szabados E, Kesmarky G, Halmosi R, Past T, et al. The effect of carvedilol on enhanced ADP-ribosylation and red blood cell membrane damage caused by free radicals. Cardiovasc Res. 2001;52:153-60.

[90] Kumar A, Dogra S. Neuroprotective effect of carvedilol, an adrenergic antagonist against colchicine induced cognitive impairment and oxidative damage in rat. Pharmacol Biochem Behav. 2009;92:25-31

[91] Kumar A, Prakash A, Dogra S. Neuroprotective effect of carvedilol against aluminium induced toxicity: possible behavioral and biochemical alterations in rats. Pharmacol Rep. 2011;63:915-23.

[92] Ma L, Gul R, Habibi J, Yang M, Pulakat L, et al. Nebivolol improves diastolic dysfunction and myocardial remodeling through reductions in oxidative stress in the transgenic (mRen2) rat. Am J Physiol Heart Circ Physiol. 2012;302:H2341-51.

[93] Park DJ, West AR. Regulation of striatal nitric oxide synthesis by local dopamine and glutamate interactions. J Neurochem. 2009;111:1457-65.

[94] West AR, Galloway MP, Grace AA. Regulation of striatal dopamine neurotransmission by nitric oxide: effector pathways and signaling mechanisms. Synapse. 2002;44:22745.

[95] Söğüt S, Zoroğlu SS, Ozyurt H, Yilmaz HR, Ozuğurlu F, et al. Changes in nitric oxide levels and antioxidant enzyme activities may have a role in the pathophysiological mechanisms involved in autism. Clin Chim Acta. 2003;331:111-7.

[96] James SJ, Melnyk S, Jernigan S, Cleves MA, Halsted CH, et al. Metabolic endophenotype and related genotypes are associated with oxidative stress in children with autism. Am J Med Genet B Neuropsychiatr Genet. 2006;141B:947-56.

[97] Essa MM, Guillemin GJ, Waly MI, Al-Sharbati MM, AlFarsi YM, et al. Increased markers of oxidative stress in autistic children of the sultanate of oman. Biol Trace Elem Res. 2012;147:25-7.

[98] Ming X, Johnson WG, Stenroos ES, Mars A, Lambert GH, Buyske S. Genetic variant of glutathione peroxidase 1 in autism. Brain Dev. 2010;32:105-9.

[99] Bowers K, Li Q, Bressler J, Avramopoulos D, Newschaffer $\mathrm{C}$, Fallin MD. Glutathione pathway gene variation and risk of autism spectrum disorders. J Neurodev Disord. 2011;3:132-43.

[100] Williams TA, Mars AE, Buyske SG, Stenroos ES, Wang R, et al. Risk of autistic disorder in affected offspring of mothers with a glutathione S-transferase P1 haplotype. Arch Pediatr Adolesc Med. 2007;161:356-61.

[101] Osborne NN, Wood JP. Metipranolol blunts nitric oxideinduced lipid peroxidation and death of retinal photoreceptors: a comparison with other anti-glaucoma drugs. Invest Ophthalmol Vis Sci. 2004;45:3787-95.

[102] Dai Y, Hou F, Buckmiller L, Fan CY, Saad A, et al. Decreased eNOS protein expression in involuting and propranolol-treated hemangiomas. Arch Otolaryngol Head Neck Surg. 2012;138:177-82. 